\title{
Real time PCR analyses of expression of E-cadherin, alpha-, beta- and gamma-catenin in human breast cancer for predicting clinical outcome
}

\author{
Amit Goyal*, Tracey A Martin, Robert E Mansel and Wen G Jiang
}

Address: Department of Surgery, School of Medicine, Cardiff University, Cardiff, UK

Email: Amit Goyal* - goyala@cf.ac.uk; Tracey A Martin - MartinTA1@cf.ac.uk; Robert E Mansel - manselre@cf.ac.uk; Wen G Jiang - jiangw@Cardiff.ac.uk

* Corresponding author

Published: II June 2008

World Journal of Surgical Oncology 2008, 6:56 doi:10.1186/1477-7819-6-56

This article is available from: http://www.wjso.com/content/6/l/56

(c) 2008 Goyal et al; licensee BioMed Central Ltd.

This is an Open Access article distributed under the terms of the Creative Commons Attribution License (http://creativecommons.org/licenses/by/2.0), which permits unrestricted use, distribution, and reproduction in any medium, provided the original work is properly cited.
Received: 24 February 2008

Accepted: II June 2008

\begin{abstract}
Background: The E-cadherin catenin system acts as an invasion suppressor of epithelial malignancies. However, it is debatable whether expression of E-cadherin or catenins is a useful prognostic marker in invasive breast cancer.

Methods: We measured the expression of E-cadherin and catenins ( $\alpha-, \beta-, \gamma$-catenin) in human breast carcinomas using real time quantitative polymerase chain reaction (Q-PCR) and investigated whether the expression levels were associated with known tumour variables or patient survival (median follow-up 72.2 months). RNA from frozen sections of breast tissue (tumour $n=124$, background normal tissue $n=33$ ) was reverse transcribed, quantified and analysed by Q-PCR with results expressed as number of copies of transcript/50 ng RNA.

Results: There was no statistically significant difference in the expression of E-cadherin and catenins $(\alpha-, \beta-, \gamma$-catenin)in the 33 paired normal background and tumour tissues. The expression of E-cadherin, $\alpha-, \beta$-, and $\gamma$-catenin in node positive tumours was similar to node-negative tumours. E-cadherin, $\alpha-, \beta$-, and $\gamma$-catenin expression in breast tumours was not related to Nottingham Prognostic Index (NPI). There was no significant difference in the expression of E-cadherin, $\alpha-, \beta$ , $\gamma$-catenin between the various TNM stages. None of the molecular markers significantly influenced survival. Lymph node status was the only significant predictor of survival.
\end{abstract}

Conclusion: Using real time quantitative PCR there was no difference in the expression of Ecadherin, $\alpha-, \beta-, \gamma$-catenin between tumour and normal breast tissue. Furthermore, measurement of expression of these molecules was not of prognostic value in predicting long term outcome of women with breast cancer.

\section{Background}

Development of malignant tumours is in part characterized by the ability of a tumour cell to overcome cell-cell adhesion and to invade surrounding tissue. The E-cadherin catenin complex localized to actin-based adherens junctions plays a crucial role in epithelial cell-cell adhesion and in the maintenance of tissue architecture. Perturbation in the expression or function of this complex results in loss of intercellular adhesion, with possible consequent cell transformation and tumour progression. 
The main structure of E-cadherin catenin complex consists of transmembrane E-cadherin, cytoplasmic proteins, called catenins ( $\alpha-, \beta$ - and $\gamma$-catenin), and actin cytoskeleton filament. $\beta$-catenin and $\gamma$-catenin share approximately $65 \%$ sequence homology and bind directly to the cytoplasmic tail of E-cadherin in a mutually exclusive manner. $\alpha$-catenin then links the bound $\beta$ - or $\gamma$-catenin to the actin microfilament network of the cytoskeleton[1,2].

In several carcinomas including gastric, head and neck, bladder, prostate, colon, and breast, a reduced or absent expression or abnormal location of E-cadherin has been observed [3-8]. Studies on both cell lines and clinical materials have provided evidence for the involvement of E-cadherin in suppressing cancer progression[5,9-13]. However, there are conflicting reports as to the usefulness of E-cadherin expression as an independent prognostic marker in invasive breast cancer [14-20]. In general, retention of E-cadherin expression correlates with well-differentiated, good prognosis and non-invasive properties[21]. Junctional catenin expression is often lost in cadherin-negative breast cancer and changes in catenin phosphorylation may compromise adhesion in cadherinpositive cancers[20,22-26]. However, few studies have investigated simultaneously the expression of E-cadherin, $\alpha-, \beta-$, and $\gamma$-catenin. The expression of the various molecular markers in previous studies has been assessed by immunohistochemical staining in a small sample size. The use of immunohistochemistry does present some drawbacks in that staining interpretation may be somewhat subjective. It is also difficult to compare different series with different cut-offs for positivity and negativity.

We determined the expression of E-cadherin, $\alpha$-, $\beta$ - and $\gamma$ catenin in human breast carcinomas using real time quantitative polymerase chain reaction and investigated whether the expression levels are associated with known tumour variables or patient survival.

\section{Methods}

\section{Patients and tumour specimens}

Tumour tissue and normal background tissue (tissue away from the primary tumour site and histologically confirmed to be free from cancer cells, from the same patients) were collected with ethical approval and informed consent from patients with invasive breast cancer. The fresh tumour and normal background tissues were snap frozen in liquid nitrogen and stored at $-70^{\circ} \mathrm{C}$.

An overview of the clinical and pathological characteristics is summarised in Table 1. Follow-up information was obtained from the patient records at the hospital and the median follow-up for patients still alive was 72.2 months (at the time of these analyses). At the beginning of the project, all the samples were re-visited histologically by a
Table I: Clinicopathological characteristics

\begin{tabular}{lc}
\hline Variable & $\mathbf{n}$ \\
\hline Tissue type & \\
Normal background & 33 \\
Tumour & 124 \\
Tumour grade & \\
I & 24 \\
2 & 42 \\
3 & 58 \\
Histology & \\
Invasive ductal & 94 \\
Invasive lobular & 14 \\
Other & 16 \\
Stage (TNM) & \\
I & 70 \\
II & 40 \\
III & 7 \\
IV & 4 \\
Unknown & 3 \\
NPI & \\
I (good prognosis) & 68 \\
2 (moderate prognosis) & 38 \\
3 (poor prognosis) & 16 \\
Unknown & 2 \\
Outcome & 85 \\
Disease free & 7 \\
Metastatic disease & 5 \\
Local recurrence & 15 \\
Death (breast cancer related) & \\
\hline
\end{tabular}

aNPI, Nottingham Prognostic Index

consultant pathologist (ADJ, Department of Pathology, Cardiff University) to confirm the histology, nature and quality of tissues, as well as tumour/stroma ratio in each tissue. These samples were subsequently used for immunohistochemical staining and extraction of genetic material.

\section{Real time-quantitative polymerase chain reaction}

The levels of E-cadherin, $\alpha$-, $\beta$ - and $\gamma$-catenin transcripts from the prepared cDNA were determined by real time quantitative RT-PCR, based on the Amplifluor ${ }^{\mathrm{TM}}$ technology, using the method previously reported[27] Specific primer pairs for E-cadherin, $\alpha$-, $\beta$ - and $\gamma$-catenin (Table 2 ) were designed by the authors using a Beacon Designer software (version 2, CA, USA) and manufactured by Invitrogen (Invitrogen Life Technologies, Paisley, Scotland, UK). An additional sequence, known as the $Z$ sequence (5'actgaacctgaccgtaca' 3 as underlined in Table 2), which is complementary to the universal $\mathrm{Z}$ probe (Intergen Inc., England, UK) was added to one of the primer in the primer pair. Each reaction included Hot-start Q-master mix (Abgene), 10 pmol of specific forward primer, $1 \mathrm{pmol}$ of reverse primer (with the $Z$ sequence), 10 pmol of FAMtagged probe (Intergen Inc.), and cDNA from approximate 50 ng RNA. An icyclerIQ ${ }^{\mathrm{TM}}$ (Bio-Rad) system, 
Table 2: Primer pairs used for real time quantitative-PCR analyses.

\begin{tabular}{|c|c|}
\hline \multicolumn{2}{|c|}{ Primers for human $\alpha$-catenin } \\
\hline ACATENINFI & caacccttgtaaacaccaat \\
\hline ACATENINZR & actgaacctgaccgtacaccttctccaagaaattctca \\
\hline \multicolumn{2}{|c|}{ Primers for human $\beta$-catenin } \\
\hline BCATENINF8 & agggattttctcagtccttc \\
\hline BCATENINZF & actgaacctgaccgtacacatgccctcatctaatgtct \\
\hline \multicolumn{2}{|c|}{ Primers for human E-Cadherin } \\
\hline ECADF8 & cagaaagttttccaccaaag \\
\hline ECADZR & actgaacctgaccgtacaaaatgtgagcaattctgctt \\
\hline \multicolumn{2}{|c|}{ Primers for human $\gamma$-catenin } \\
\hline gCatFI & aacaagaacaaccccaagtt \\
\hline gCatZr & actgaacctgaccgtacatagttacgcatgatctgcac \\
\hline
\end{tabular}

equipped with an optical unit that allows real-time detection of 96 reactions was used to amplify the plasmid standards and breast tissue samples under the following conditions: $94^{\circ} \mathrm{C}$ for 12 minutes; 50 cycles of $94^{\circ} \mathrm{C}$ for 15 $\mathrm{s}, 55^{\circ} \mathrm{C}$ for 40 seconds and $72{ }^{\circ} \mathrm{C}$ for 20 seconds. The purified plasmids served as internal standards and helped in calculating the level of each tight junction molecule cDNA (copies per 50 ng RNA) in the tissue samples. The products of Q-PCR were verified on agarose gels.

\section{Antibodies}

The primary antibodies used were monoclonal anti-E-cadherin (HECD-1, mouse IgG1 1:50, R\&D systems, Oxon, UK), anti- $\alpha$-catenin (rabbit IgG1 1:50 dilution; Sigma), anti- $\beta$-catenin (mouse IgG1 1:100, R\&D systems, Oxon, UK) and anti- $\gamma$-catenin (mouse IgG1 1:100, Sigma).

\section{Immunohistochemical staining}

Immunohistochemical staining was performed on 25 matched tumour and normal background tissue pairs. Frozen sections of breast tumor and normal background tissue were cut at a thickness of $6 \mu \mathrm{m}$ using a cryostat. The sections were mounted on Super Frost Plus microscope slides, air-dried and then fixed in a mixture of $50 \%$ acetone and 50\% methanol. The sections were then placed in 'Optimax' (Vector Laboratories Ltd, Peterborough, UK) wash buffer for 5-10 min to rehydrate. Sections were incubated for $20 \mathrm{~min}$ in a $0.6 \%$ BSA blocking solution and probed with the primary antibody. Following extensive washings, sections were incubated for $30 \mathrm{~min}$ in the secondary biotinylated antibody (Multilink Swine anti-goat/ mouse/rabbit immunoglobulin; Dako Inc.). Following washings, Avidin Biotin Complex (Vector Laboratories Ltd) was then applied to the sections, followed by extensive washings. Diaminobenzidine chromogen (Vector Laboratories Ltd) was then added to the sections, which were incubated in the dark for 5 minutes. Sections were then counterstained in Mayer's haematoxylin and dehydrated in ascending grades of methanol before clearing in xylene and mounting under a coverslip.

\section{Quantitative image analysis of immunohistochemical stains \\ Image acquisition and processing}

Slides were viewed using a $20 \times 20$ objective lens (Leitz, DM IRB) and images were subsequently saved as a 24 bit colour JPEG file image via a digital camera (Panasonic, digital), and computer (Pentium III, RM machines, Milton Keynes UK) equipped with a frame grabber (Win TV, Celebrity Edition from Hauppauge). The captured images of tumour and normal background tissues were amalgamated using the PHOTOMERGE option in Adobe Photoshop 6 . The images were then converted into gray scale images and inverted using Adobe Photoshop 6 before analysing using Optimas image analysis software (Version 6, Optimas, UK).

The intensity was analysed using point morphometry. 10 representative points were marked on each image captured. Overall, optical intensity data (mean and SD) was calculated by summing up the data from all images in the two groups and subtracting the mean background reading.

\section{Statistical analysis}

The data obtained was analysed using the MINITAB 13.32 (Minitab Inc. State College, PA, USA) programme. Statistical significance was calculated using the two-sample student t-test, non-parametric Mann-Whitney test and ANOVA where appropriate. Multivariate analysis was done for survival.

\section{Results}

The intensity of membrane staining for E-cadherin and all catenin molecules was significantly more in normal background tissues compared with tumour tissues (mean \pm SD; E-cadherin normal background $169.6 \pm 5.83$, tumour $82.7 \pm 12.78$ p $<0.001 ; \alpha$-catenin normal background $163.22 \pm 4.27$, tumour $92.22 \pm 21.02 \mathrm{p}<0.001, \beta$-catenin normal background $216.1 \pm 15.94$, tumour $99 \pm 32.93 \mathrm{p}$ $<0.001, \gamma$-catenin normal background $131.9 \pm 24.99$, tumour $85.5 \pm 29.93 \mathrm{p}=0.008$ ).

In contrast, no statistically significant difference was seen in the expression of E-cadherin, $\alpha$-catenin, $\beta$-catenin and $\gamma$-catenin in the 33 paired normal background and tumour tissues (copies/50 ng RNA, mean \pm SD: E-cadherin normal background $17.4 \pm 3.8$, tumour $16.5 \pm 6.7 \mathrm{p}$ $=0.51 ; \alpha$-catenin normal background $13.5 \pm 4.5$, tumour $38.3 \pm 30.3 \mathrm{p}=0.48, \beta$-catenin normal background 0.048 \pm 0.029 , tumour $0.057 \pm 0.019 \mathrm{p}=0.68, \gamma$-catenin normal 
background $1.255 \pm 0.927$, tumour $0.219 \pm 0.157 \mathrm{p}=$ $0.28)$.

The expression of E-cadherin, $\alpha$-, $\beta$ - and $\gamma$-catenin in node positive tumours was similar to node-negative tumours (copies/50 ng RNA, mean \pm SD: E-cadherin node positive $35.5 \pm 104.2$, node negative $25.70 \pm 35.13 \mathrm{p}=0.51 ; \alpha$-catenin node positive $26.60 \pm 61.79$, node negative $17.25 \pm$ $23.08 \mathrm{p}=0.84, \beta$-catenin node positive $0.0973 \pm 0.2003$, node negative $0.0895 \pm 0.1686 \mathrm{p}=0.69, \gamma$-catenin node positive $0.635 \pm 4.004$ node negative $0.622 \pm 1.948 \mathrm{p}=$ 0.55).

There was no significant relationship of E-cadherin, $\alpha$-catenin, $\beta$-catenin and $\gamma$-catenin in breast tumours to Nottingham Prognostic Index (NPI) (E-cadherin $p=0.094, \alpha$ catenin $\mathrm{p}=0.144, \beta$-catenin $\mathrm{p}=0.378, \gamma$-catenin $\mathrm{p}=$ $0.131)$.

There was a trend towards decreased E-cadherin expression in Grade 2 and 3 tumours compared to Grade 1 tumours but the differences were not statistically significant. $\alpha$-catenin expression was significantly increased in Grade 2 tumours compared with Grade 1 tumours ( $\mathrm{p}=$ $0.03)$. However, $\alpha$-catenin expression in Grade 3 tumours was similar to Grade 1 tumours. $\beta$-catenin expression was similar in Grade 1 and 2 tumours. However, its expression was significantly increased in Grade 3 tumours compared to Grade 2 tumours $(\mathrm{p}=0.054)$. $\gamma$-catenin expression was similar in the 3 groups.

Surprisingly, there was no difference in the expression of E-cadherin catenin complex between ductal and lobular tumours.

The TNM Stages 3 and 4 were combined into a single group for analyses as they were very small. There was no significant difference in the expression of E-cadherin, $\alpha_{-}$, $\beta-$, and $\gamma$-catenin between the various TNM stages ( $\mathrm{p}=$ $0.282, \mathrm{p}=0.806, \mathrm{p}=0.838, \mathrm{p}=0.337$ respectively).

E-cadherin expression in tumours of patients who were disease free was significantly more compared to those with metastatic disease, local recurrence or dying from breast cancer (Disease free vs. poor outcome (metastatic disease and/or local recurrence and/or death from breast cancer) $\mathrm{p}=0.012$ ). There was no difference in $\alpha$-catenin and $\gamma$-catenin expression between the groups. $\beta$-catenin expression was increased in patients dying from breast cancer compared to disease free patients and the difference approached statistical significance $(p=0.052)$. Multivariate analysis was done using SPSS for mortality. None of the molecular markers significantly influenced survival. Lymph node status was the only significant predictor of survival.

\section{Discussion}

In this study, we examined the expression of cell-cell adhesion molecules E-cadherin, $\alpha-, \beta$ - and $\gamma$-catenin in human breast cancer by quantitative real time polymerase chain reaction. The mRNA levels of these markers were related to clinicopathological variables and survival data.

The data from this study did not show any difference in the expression of E-cahderin, $\alpha-, \beta$ - and $\gamma$-catenin between tumour and related normal tissue. This contrasts with the results of immunohistochemical staining in the present study and most previously reported studies of E-cadherin catenin complex in breast cancer, which have described down-regulation of some of these molecules in tumourigenesis[20,23-26,28].

The disparity can be easily explained as this is the first study to measure expression of the E-cadherin catenin complex molecules by quantitative real time polymerase chain reaction. Direct comparisons are not possible as previous studies have varied widely in patient samples and immunohistochemical scoring methods, which make comparisons difficult.

It is possible that a defect in the E-cadherin catenin complex without a change in its expression may be responsible for the malignant progression. Immunohistochemical staining and Q-PCR reveal different information and each has its advantages and disadvantages. Immunohistochemical analysis provides vital information on the protein location in the cells, which is important when studying cell adhesion molecules. However, the method has obvious limitations in quantifying the true amount of the protein in cells or tissues. Quantitative analysis of mRNA as presented here has the unique advantage in providing quantitative information of the gene expression concerned. However, this method does not provide information about the location of the molecule within a cell and may be considered 'over-sensitive'.

The expression of E-cadherin, $\alpha_{-}, \beta$ - and $\gamma$-catenin was similar in node positive and node negative tumours. Our results suggest that expression of E-cadherin, $\alpha-, \beta$ - and $\gamma$ catenin may persist into the later stages of breast carcinoma. Siitonen et al. and Oka et al. found a correlation between loss of E-cadherin and the presence of nodal metastases[29,30], but this has not been widely reported. Howard et al. recently reported increased E-cadherin expression in tumour tissue with nodal metastases[14]. Ecadherin expression is retained in inflammatory breast cancer[31]. Furthermore, derivative metastases frequently show strong E-cadherin expression[32]. One emerging opinion is that dynamic, reversible modulation of E-cadherin catenin complex occurs during breast carcinoma progression. E-cadherin catenin complex expression or 
function is transiently reduced at the development stage of primary tumours. This loss of adhesiveness at primary site of tumours allows cancer cells to 'dissociate' from each other. However, following invasion and degradation of surrounding matrix, and migration into the vasculature and surrounding tissue, E-cadherin catenin complex is reintroduced and cells adhere to the vasculature and form tumour emboli[14].

In contrast to most previous IHC studies [33-35], mRNA expression of E-cadherin, $\alpha-, \beta$ - and $\gamma$-catenin was similar in ductal and lobular tumours. This may be due to the fact that quantitative analysis as given here reflects the total amount of the molecule rather than in an individual cell and that mRNA expression does not always correlate with cellular protein expression. Moreover, most series reported on membrane staining and did not include cytoplasmic staining as a separate category. Thus, it is possible that lobular carcinoma cases with cytoplasmic staining were included in the general category of reduced expression of E-cadherin staining.

E-cadherin expression was not associated with tumour grade. Reduced E-cadherin expression has been associated in the past with high histological grade[19,36]. Our results suggest that this is not necessarily the case. Preserved or increased E-cadherin catenin expression supports the notion that it assists aggressive tumour growth by providing a support structure for cells to adhere and accelerates invasion and metastasis.

There are conflicting reports in the literature regarding the relationship between E-cadherin catenin complex and prognosis/survival. In this study, E-cadherin catenin complex expression was not prognostic in breast cancer patients or related to survival. Asgeirsson et al., and Heimann $e t$ al., reported reduced expression of E-cadherin to be associated with tumour recurrence, metastases, and poor prognosis in breast cancer[15,16]. Not all studies confirm these findings[14,19,37]. Other investigators have shown that the abnormal expression of catenins is related to poor prognosis or decreased survival[20,23,26,38].

Despite the apparent advantages of quantitation and sensitivity, the use of quantitative real time polymerase chain reaction does present some drawbacks. The technique is highly sensitive and any contaminating cells (lymphocytes, stromal tissue) will lead to readings that belong to non cancer cells. To overcome this problem, it is essential to isolate pure populations of tumour cells by micro dissection.

\section{Conclusion}

In conclusion, using real time quantitative PCR we have shown that there is no difference in the expression of $\mathrm{E}$ cahderin, $\alpha-, \beta$ - and $\gamma$-catenin between tumour and normal breast tissue. Furthermore, measurement of expression of these molecules is not of prognostic value in predicting long term outcome of women with breast cancer.

\section{Competing interests}

The authors declare that they have no competing interests.

\section{Authors' contributions}

AG conducted the study, analyzed the data and prepared the manuscript, TAM contributed to the conduct of the study, REM contributed to clinical follow ups and helped in editing the manuscript, WGJ contributed to the conduct of the study, design of primers and statistical analysis.

\section{Acknowledgements}

Immunohistochemical staining was performed by Gareth Watkins.

\section{References}

I. Nagafuchi A, Takeichi M: Transmembrane control of cadherinmediated cell adhesion: a $94 \mathrm{kDa}$ protein functionally associated with a specific region of the cytoplasmic domain of $E$ cadherin. Cell Regul 1989, I:37-44.

2. Ozawa M, Kemler R: Molecular organization of the uvomorulin-catenin complex. J Cell Biol 1992, I I 6:989-996.

3. Bukholm IK, Nesland JM, Karesen R, Jacobsen U, Borresen-Dale AL: Expression of E-cadherin and its relation to the $\mathrm{p} 53$ protein status in human breast carcinomas. Virchows Arch 1997, 43I:317-32I.

4. Glukhova M, Koteliansky V, Sastre X, Thiery JP: Adhesion systems in normal breast and in invasive breast carcinoma. Am J Pathol 1995, | 46:706-7|6.

5. Gamallo C, Palacios J, Suarez A, Pizarro A, Navarro P, Quintanilla M, Cano A: Correlation of E-cadherin expression with differentiation grade and histological type in breast carcinoma. Am J Pathol 1993, I42:987-993.

6. Bringuier PP, Umbas R, Schaafsma HE, Karthaus HF, Debruyne FM, Schalken JA: Decreased E-cadherin immunoreactivity correlates with poor survival in patients with bladder tumors. Cancer Res 1993, 53:324|-3245.

7. Schipper JH, Frixen UH, Behrens J, Unger A, Jahnke K, Birchmeier W: E-cadherin expression in squamous cell carcinomas of head and neck: inverse correlation with tumor dedifferentiation and lymph node metastasis. Cancer Res I99I, 5 I:6328-6337.

8. Mayer B, Johnson JP, Leitl F, Jauch KW, Heiss MM, Schildberg FW, Birchmeier W, Funke I: E-cadherin expression in primary and metastatic gastric cancer: down-regulation correlates with cellular dedifferentiation and glandular disintegration. Cancer Res 1993, 53:1690-1695.

9. Chen WC, Obrink B: Cell-cell contacts mediated by E-cadherin (uvomorulin) restrict invasive behavior of L-cells. I Cell Biol |991, I | 4:319-327.

10. Frixen UH, Behrens J, Sachs M, Eberle G, Voss B, Warda A, Lochner $D$, Birchmeier $W$ : E-cadherin-mediated cell-cell adhesion prevents invasiveness of human carcinoma cells. J Cell Biol I99I, I 13:173-185.

II. Kadowaki T, Shiozaki H, Inoue M, Tamura S, Oka H, Doki Y, lihara K, Matsui S, Iwazawa T, Nagafuchi A, .: E-cadherin and alpha-catenin expression in human esophageal cancer. Cancer Res 1994, 54:291-296

12. Lipponen P, Saarelainen E, Ji H, Aaltomaa S, Syrjanen K: Expression of E-cadherin (E-CD) as related to other prognostic factors and survival in breast cancer. J Pathol 1994, I74:101-109. 
13. Pierceall WE, Woodard AS, Morrow JS, Rimm D, Fearon ER: Frequent alterations in E-cadherin and alpha- and beta-catenin expression in human breast cancer cell lines. Oncogene 1995, I I:I319-I326

14. Howard EM, Lau SK, Lyles RH, Birdsong GG, Umbreit JN, Kochhar R: Expression of e-cadherin in high-risk breast cancer. J Cancer Res Clin Oncol 2005, I3 I: | 4- I8.

15. Asgeirsson KS, JG J, Tryggvad inverted question L, Olafsd inverted question K, JR S, Ingvarsson S, HM O: Altered expression of Ecadherin in breast cancer. patterns, mechanisms and clinical significance. Eur J Cancer 2000, 36:1098-1106.

16. Heimann R, Lan F, McBride R, Hellman S: Separating favorable from unfavorable prognostic markers in breast cancer: the role of E-cadherin. Cancer Res 2000, 60:298-304.

17. Howard EM, Lau SK, Lyles RH, Birdsong GG, Tadros TS, Umbreit JN Kochhar R: Correlation and expression of p53, HER-2, vascular endothelial growth factor (VEGF), and e-cadherin in a high-risk breast-cancer population. Int J Clin Oncol 2004, 9:154-160.

18. Kleer CG, van Golen KL, Braun T, Merajver SD: Persistent E-cadherin expression in inflammatory breast cancer. Mod Pathol 200I, I 4:458-464.

19. Parker C, Rampaul RS, Pinder SE, Bell JA, Wencyk PM, Blamey RW, Nicholson RI, Robertson JF: E-cadherin as a prognostic indicator in primary breast cancer. $\mathrm{Br} /$ Cancer 200I, 85: 1958-1963.

20. Bukholm IK, Nesland JM, Karesen R, Jacobsen U, Borresen-Dale AL: E-cadherin and alpha-, beta-, and gamma-catenin protein expression in relation to metastasis in human breast carcinoma. J Pathol 1998, 185:262-266.

21. Berx G, Van Roy F: The E-cadherin/catenin complex: an important gatekeeper in breast cancer tumorigenesis and malignant progression. Breast Cancer Res 200I, 3:289-293.

22. Rimm DL, Sinard JH, Morrow JS: Reduced alpha-catenin and Ecadherin expression in breast cancer. Lab Invest 1995 72:506-5/2.

23. Nakopoulou L, Gakiopoulou-Givalou H, Karayiannakis AJ, Giannopoulou I, Keramopoulos A, Davaris P, Pignatelli M: Abnormal alphacatenin expression in invasive breast cancer correlates with poor patient survival. Histopathology 2002, 40:536-546.

24. Gonzalez MA, Pinder SE, Wencyk PM, Bell JA, Elston CW, Nicholson RI, Robertson JF, Blamey RW, Ellis IO: An immunohistochemical examination of the expression of E-cadherin, alpha- and beta/gamma-catenins, and alpha2- and betal-integrins in invasive breast cancer. J Pathol 1999, 187:523-529.

25. Dillon DA, D'Aquila T, Reynolds AB, Fearon ER, Rimm DL: The expression of pI $20 \mathrm{ctn}$ protein in breast cancer is independent of alpha- and beta-catenin and E-cadherin. Am J Pathol 1998, I52:75-82.

26. Zschiesche W, Schonborn I, Behrens J, Herrenknecht K, Hartveit F, Lilleng P, Birchmeier W: Expression of E-cadherin and catenins in invasive mammary carcinomas. Anticancer Res 1997, 17:561-567.

27. Jiang WG, Sampson J, Martin TA, Lee-Jones L, Watkins G, DouglasJones A, Mokbel K, Mansel RE: Tuberin and hamartin are aberrantly expressed and linked to clinical outcome in human breast cancer: The role of promoter methylation of TSC genes. Eur J Cancer 2005, 41:1628-1636.

28. Jiang WG, Mansel RE: E-cadherin complex and its abnormalities in human breast cancer. Surg Oncol 2000, 9:15I-I7|.

29. Oka H, Shiozaki H, Kobayashi K, Inoue M, Tahara H, Kobayashi T, Takatsuka Y, Matsuyoshi N, Hirano S, Takeichi M, .: Expression of E-cadherin cell adhesion molecules in human breast cancer tissues and its relationship to metastasis. Cancer Res 1993, 53:|696-I70I.

30. Siitonen SM, Kononen JT, Helin HJ, Rantala IS, Holli KA, Isola JJ: Reduced E-cadherin expression is associated with invasiveness and unfavorable prognosis in breast cancer. Am J Clin Pathol 1996, 105:394-402.

31. Charafe-Jauffret E, Tarpin C, Bardou VJ, Bertucci F, Ginestier C, Braud AC, Puig B, Geneix J, Hassoun J, Birnbaum D, Jacquemier J, Viens $P$ : Immunophenotypic analysis of inflammatory breast cancers: identification of an 'inflammatory signature'. J Pathol 2004, 202:265-273.

32. Kowalski PJ, Rubin MA, Kleer CG: E-cadherin expression in primary carcinomas of the breast and its distant metastases. Breast Cancer Res 2003, 5:R2 I7-R222.
33. De Leeuw W], Berx G, Vos CB, Peterse JL, Van de Vijver MJ, Litvinov S, Van Roy F, Cornelisse CJ, Cleton-Jansen AM: Simultaneous loss of E-cadherin and catenins in invasive lobular breast cancer and lobular carcinoma in situ. J Pathol I997, 183:404-4II.

34. Wahed A, Connelly J, Reese T: E-cadherin expression in pleomorphic lobular carcinoma: an aid to differentiation from ductal carcinoma. Ann Diagn Pathol 2002, 6:349-35I.

35. Acs G, Lawton TJ, Rebbeck TR, LiVolsi VA, Zhang PJ: Differential expression of E-cadherin in lobular and ductal neoplasms of the breast and its biologic and diagnostic implications. Am J Clin Pathol 200I, I I 5:85-98.

36. Charpin C, Garcia S, Bouvier C, Devictor B, Andrac L, Choux R, Lavaut M: E-cadherin quantitative immunocytochemical assays in breast carcinomas. J Pathol 1997, 18 I:294-300.

37. Gillett CE, Miles DW, Ryder K, Skilton D, Liebman RD, Springall RJ, Barnes DM, Hanby AM: Retention of the expression of E-cadherin and catenins is associated with shorter survival in grade III ductal carcinoma of the breast. J Pathol 200I, 193:433-44I.

38. Yoshida R, Kimura N, Harada Y, Ohuchi N: The loss of E-cadherin, alpha- and beta-catenin expression is associated with metastasis and poor prognosis in invasive breast cancer. Int $J$ Oncol 200I, I8:513-520.
Publish with Bio Med Central and every scientist can read your work free of charge

"BioMed Central will be the most significant development for disseminating the results of biomedical research in our lifetime. "

Sir Paul Nurse, Cancer Research UK

Your research papers will be:

- available free of charge to the entire biomedical community

- peer reviewed and published immediately upon acceptance

- cited in PubMed and archived on PubMed Central

- yours - you keep the copyright
BioMedcentral 